\title{
REFLEXIA ŽIVOTA A DIELA CYRILA A METODA V TELEVÍZNEJ, FILMOVEJ I INTERNETOVEJ TVORBE OD OSEMDESIATYCH ROKOV MINULÉHO STOROČIA PO SÚČASNOST̄ ${ }^{1}$
}

\author{
Reflection of the Life and Work of Cyril and Methodius in Television, \\ Film and Internet Production from the 1980s to the Present
}

\author{
Štefan Timko
}

DOI: 10.17846/CL.2019.12.1.159-171

\begin{abstract}
TIMKO, Štefan. Reflection of the Life and Work of Cyril and Methodius in Television, Film and Internet Production from the 1980s to the Present. The study focuses on the reflection of the life and work of Saints Cyril and Methodius in the Czech and Slovak media production from the late 1980s to the present. It mainly maps feature films and television production, but it also mentions relevant documentary and cartoon movies that have emerged in the last decade. The final part also deals with the image of "Brothers from Thessaloniki" in the audiovisual works and series presented on the Internet, which usually bring a less conventional or ironic view of these saints and the period of Great Moravia. Interpretative analysis is used as the original method for dealing with individual audiovisual works, giving an emphasis on defining their genre definition, narrative structure and central themes. The analysis of the images of the historical figures of Cyril and Methodius and their contemporaries, depending on the period, the social and political situation and the country in which the audiovisual production was created, is also an important subject of the study. It reflects the social relevance of the analyzed productions and considers its causes.
\end{abstract}

Keywords: life and works of Cyril and Methodius, Czech and Slovak film and television production, Internet productions

\begin{abstract}
Abstrakt: TIMKO, Štefan. Reflexia života a diela Cyrila a Metoda v televíznej, filmovej i internetovej tvorbe od osemdesiatych rokov minulého storočia po súčasnost. Štúdia sa venuje reflexii života a diela svätcov Cyrila a Metoda v českej a slovenskej audiovizuálnej tvorbe od konca osemdesiatych rokov minulého storočia po súčasnost'. Mapuje predovšetkým hrané filmové a televízne diela, ale okrajovo sa zaoberá aj relevantnými dokumentárnymi a kreslenými filmami, ktoré vznikli v poslednom desatročí. Finálna čast práce sa venuje obrazu solúnskych bratov v rámci audiovizuálnych diel a seriálov uvádzaných na internetovej platforme, ktoré prinášajú zvyčajne menej konvenčný či ironizujúci pohlad na týchto svätcov i obdobie Velkej Moravy. Východiskovou metódou je interpretačná analýza jednotlivých audiovizuálnych diel, s dôrazom na definovanie ich žánrového vymedzenia, naratívnej štruktúry a ústredných motívov. Významným predmetom skúmania je aj analýza stvárnenia historických postáv Cyrila a Metoda a ich súčasníkov v závislosti od obdobia, spoločenskej i politickej situácie
\end{abstract}

Táto práca bola podporovaná Agentúrou na podporu výskumu a vývoja v rámci projektu Literatúra a jej filmová podoba v stredoeurópskom kontexte na základe Zmluvy č. APVV-17-0012. 
a aj krajiny, v ktorej dielo vzniklo. Práca reflektuje tiež spoločenskú relevantnost̉ daných snímok a zamýšla sa nad jej príčinami.

Klúčové slová: život a dielo Cyrila a Metoda, česká a slovenská filmová a televízna tvorba, tvorba na internetovej platforme

\section{Prvé audiovizuálne hrané diela o Cyrilovi a Metodovi}

Postavy sv. Cyrila a Metoda a ich velkomoravská misia sa stali inšpiráciou pre mnohé slovenské umelecké diela. V slovenskej literatúre sa objavili v období baroka a s príchodom slovenského národného obrodenia koncom 18. stor. sa cyrilo-metodská tematika stala $\mathrm{v}$ našej poézii, próze, dramatickom, výtvarnom i hudobnom umení mimoriadne frekventovanou. ${ }^{2} \mathrm{~V}$ televíznej či filmovej tvorbe na Slovensku sa však s osudom solúnskych bratov stretávame len ojedinele, pričom diela reflektujúce ich život a odkaz sa v spomínaných médiách objavujú až v posledných troch desatročiach.

Rezervovanost' slovenskej hranej televíznej a filmovej tvorby voči príbehu a odkazu Cyrila a Metoda má niekol'ko dôvodov. V rokoch 1948 až 1989 to bola predovšetkým politická situácia neprajúca objektívnej prezentácii týchto osobností v médiách, ktoré výrazne podliehali štátnej kontrole i cenzúre. Komunistická moc so zahranično-politickou orientáciou na Sovietsky zväz vyzdvihovala Vel'kú Moravu ako žriedlo panslovanského kultúrneho odkazu a Cyrila a Metoda prezentovala ako údajných bojovníkov proti násilnej germanizácii (Kopal 2014, 207). Oceňovala solúnskych bratov aj ako tvorcov prvého slovanského literárneho jazyka a abecedy, no problematické bolo ich poslanie ako šíritelov krestanstva a významných predstavitelov cirkvi. Po roku 1989 narážali snahy o približenie osudov vierozvestcov zo Solúna predovšetkým na finančné prekážky a zmenu orientácie slovenskej (i stredoeurópskej) kinematografie výraznejšie sa otvárajúcej únikovým snímkam pre intelektuálne menej náročné široké divácke publikum. Príbeh z 9. storočia si štandardne vyžadoval spracovanie v rámci žánru historickej drámy, ktorý patrí medzi náročné filmové žánre, nielen nákladmi, ale aj produkciou. Konzervatívny a pietny obraz Cyrila a Metoda v spoločnosti, vychádzajúci z doterajšej umeleckej tradície, podporovaný štátnymi i cirkevnými predstavitel'mi, výrazne stažoval snahy tvorcov vytvorit’ zo solúnskych bratov hrdinov masovo atraktívnych a ziskových audiovizuálnych diel.

Velkomoravské dejiny a jej významní predstavitelia sa objavili v slovenských televíznych inscenáciách osemdesiatych rokov Mojmír II (r. M. Pietor, 1981), Samo, kupec a král' (r. P. Haspra) a Svätopluk (r. J. Zachar, 1989) (Kopal 2014, 218-219). V polovici osemdesiatych rokov minulého storočia sa Velká Morava mala stat' námetom pre rovnomenný slovenský vel'kofilm. Projekt režiséra Andreja Lettricha mal pozostávat z troch dielov Samo, Rastislav a Svätopluk. Záverečná čast̉ filmu v scenáristickom spracovaní Milana Ferka sa mala venovat aj cyrilo-metodskej misii, no tá sa stala ideologicky najspornejšou i výrazne kritizovanou častou celého projektu (Kopal 2014, 211). ${ }^{3}$

2 Misionárska činnost̉ Cyrila a Metoda je spomenutá v prvom slovenskom tlačenom katolíckom zborníku Cantus Catholici vydanom v roku 1655, ktorý zostavil Benedikt Szöllösi. V období osvietenstva nájdeme zmienku o solúnskych bratoch v predhovore Mateja Bela ku Gramatike česko-slovenskej (Grammatica slavico-bohemica) od Pavla Doležala z roku 1746. V časoch slovenského národného obrodenia sa objavuje cyrilo-metodská téma napríklad v literárnych dielach Juraja Fándlyho, Jána Hollého, Jána Kolára, Ludovíta Štúra, Andreja Sládkoviča či Jozefa Miloslava Hurbana.

3 Film Velká Morava, ktorý mal byt koprodukčným projektom medzi štúdiami Koliba, Gottwaldov a Barrandov, sa napokon nezrealizoval kvôli odmietavým reakciám českej strany (Kopal 2014, 207). 
Prvou televíznou snímkou tematizujúcou život sv. Cyrila a Metoda sa stala televízna inscenácia Solúnski bratia z roku 1989. Vznikla podla scenára slovenského prozaika a dramatika Milana Ferka, ktorý sa vo svojich prózach (napr. Svätopluk, Svätopluk a Metod, Svätoplukovo dedičstvo, Velkomoravské záhady) i v drámach (Pomsta Pribinova, Pravda Svätoplukova, Obrana Metodova, Svadba Svätoplukova, Smrt' Gorazdova, Nádej Mojmírova) frekventovane venoval významným osobnostiam i udalostiam Velkej Moravy. V dvojdielnej televíznej inscenácii Solúnski bratia sa Milan Ferko zameral na obdobie trojročného pôsobenia (867 - 869) Konštantína a Metoda v Ríme. Po tom, ako v rokoch 863 až 867 na Vel'kej Morave uplatnili Konštantínom vytvorenú novú abecedu a preložili do staroslovienčiny základné liturgické diela, rozhodli sa íst’ do Ríma, aby na dvore pápeža Hadriána II. realizovali svoj zámer: obhájili prvé slovanské písmo (hlaholiku), dosiahli schválenie kníh preložených do staroslovienčiny a presadili požiadavku samostatnej panónskoslovienskej diecézy. V Ríme sa odohráva ústredný dramatický konflikt medzi Konštantínom a Metodom na jednej strane, ktorí nezištne obhajujú záujmy Velkej Moravy a aj každého národa i človeka na rovnoprávnost', a predstavitelmi franského kléru, ktorí sa im intrigami snažia tieto zámery prekazit'. Ako ústredný iniciátor intríg je v inscenácii zobrazený franský duchovný Viching, ktorý sa v roku 880 stal nitrianskym biskupom. Milan Ferko rozvíja v inscenácii aj romantickú líniu platonického vztahu Hadriánovej dcéry Agáty ku Konštantínovi. Agáta je očarená učencovou osobnostou i jeho názormi a má výrazný vplyv na to, že pápež Hadrián uzná požiadavky Konštantína a Metoda. Pápežova dcéra je neskôr unesená a na Vichingov podnet zavraždená rímskym vojakom Eleutérom. Takýto motív s príchutou konšpiračnej teórie mohol Ferko vytvorit’ aj vd’aka tomu, že podla historických prameňov bola pápežova dcéra naozaj v roku 868 unesená a zavraždená, spolu so svojou matkou. ${ }^{4}$ Ďalší plán inscenácie Solúnski bratia opisuje aj spor kniežata Rastislava a jeho synovca Svätopluka. Kým Rastislav je nemilosrdný voči Franskej ríši a jej cirkevných predstavitel’ov vypovie z Vel'kej Moravy, Svätopluk je tu zobrazený ako pragmatický diplomat, usilujúci o nekonfliktný vztah s Franskou ríšou.

Inscenácia Solúnski bratia je síce autorskou fikciou, opiera sa o mnohé historické fakty a historické osobnosti. Zaujme prepracovanými a diferencovanými charaktermi postáv, najmä ústredných hrdinov. Kým Konštantín je zobrazený ako introvertný, hlibavý a často pochybujúci muž, Metod má pragmatickejšiu a ráznejšiu povahu. Títo hrdinovia často prichádzajú do konfliktov z rôznymi typmi výrazne menej sympatických postáv, od sofistikovaného intrigána Vichinga, tažko čitatelného kardinála Formosu, až po menej obratného zradcu z radov vierozvestcov Vavrinca. Výraznou zmenou postoja v dráme prejde len pápež Hadrián II., ktorý sa od nevýraznej a váhavej postavy často podliehajúcej vplyvu kléru, aj s prispením rodinnej tragédie, vyprofiluje v osvietenú a nezávislú osobnost'. Film síce ponúka v tej dobe tradičný obraz cirkvi ako spoločenstva intrigánov a oportunistov, ale do kontrastu s nimi ponúka aj obraz ústredných cirkevných predstavitelov $\mathrm{s}$ autentickou vierou. Takéto zobrazenie krestanských hrdinov bolo možné len vd’aka politickému odmäku v prestavbovom Československu. Televízna inscenácia Solúnski bratia je ukážkou nielen nadpriemernej scenáristickej práce Milana Ferka, ale aj citlivej a sofistikovanej réžie Pavla Haspru, ktorý s využitím popredných slovenských divadelných hercov (v hlavných úlohách sa predstavili Štefan Kvietik a Emil Horváth ml.) dokázal vytvorit vierohodný a emocionálne silný obraz zápasu solúnskych bratov o sebaurčenie a kultúrne povznesenie Vel'kej Moravy.

Po roku 1989 a predovšetkým po vzniku samostatnej Slovenskej republiky sa stala cyrilo-metodská tradícia i obdobie Vel'kej Moravy výraznejšie medializovanou témou ako doposial'. Vládnuce špičky novovznikajúcej republiky sa hlásili k odkazu Svätopluka, Cyrila i Metoda. V roku 1996 boli stvárnení solúnski bratia v polhodinovom televíznom filme Povest’ o Cyrilovi a Metodovi z cyklu Hrady a povesti. Toto dielo režiséra Luboša Midriaka vzniklo na motívy

4 Vo Ferkovej inscenácii však zomiera iba Agáta, jej matka Štefánia sa neskôr utiahne do kláštora. 
Starých povestí slovenských od Milana Ferka a reprezentuje žáner dramatizovaného dokumentárneho filmu. Rozprávač Michal Ďuriš v ňom približuje zásadné udalosti spojené s pôsobením Cyrila a Metoda na Velkej Morave. Navonok odborný štýl komentára ja zafarbený konfesným pohladom na solúnskych bratov ako poslov Božích ${ }^{5}$. Komentár je sprevádzaný niekolkými krátkymi hranými scénkami, ktoré didakticky približujú najvýznamnejšie momenty príbehu vierozvestcov. V kontraste s kultivovaným a civilne pôsobiacim prejavom Michala Ďuriša sú však tieto scénky stvárnené amatérskymi hercami poznamenané ovela nižšou mierou autentickosti a sú prezentované s preexponovaným pátosom. ${ }^{6}$

V roku 1998 zrežíroval Martin Kákoš televízny film Knieža, podla románu vtedajšieho slovenského ministra kultúry Ivana Hudeca. Jeho ústrednou témou sú osudy nitrianskeho kniežata Pribinu, ktorý bol zo svojej ríše vyhnaný moravským kniežatom Mojmírom. Schematický scenár jasne vyzdvihuje charakter nitrianskeho kniežata a konfrontuje ho s podlým a zlým Mojmírom. V záverečných titulkoch však nezabúda spomenút aj odkaz Cyrila a Metoda. Televízny film Knieža je možné zaradit k tzv. „národným“ filmom, ktorých úlohou bolo propagovat údajné korene novovzniknutého štátu počas vlády premiéra Vladimíra Mečiara. Na televíznom filme Knieža sa okrem Slovenskej televízie podielalo aj čerstvo sprivatizované Štúdio Koliba, ktoré malo produkovat’ „národné“ velkofilmy pre kiná Jánošík a Pribina. Tieto filmy však napriek štedrej dotácii štátu ne-

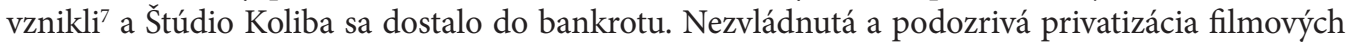
ateliérov na Kolibe po roku 1996 na dlhú dobu nielen zabrzdila rozvoj slovenskej filmovej tvorby, ale predovšetkým na dlhé obdobie odradila tvorcov a producentov (s korektnými úmyslami) púštat sa do vel'korozpočtových projektov historických filmov s národnou tematikou.

\section{Rok 2013 - rok vzkriesenia záujmu o cyrilo-metodskú tradíciu v slovenskej kinematografii}

Výraznejšie snahy o produkciu hraných filmov s tematikou osudov Cyrila a Metoda sa začali na Slovensku opät' objavovat' až pred rokom 2013. Okrem primárneho dôvodu osláv 1150. výročia príchodu Cyrila a Metoda na naše územie boli tieto úsilia podporené aj d’alšími faktormi. Začiatkom tohto tisícročia sa začali zintenzívňovat filmové koprodukcie v strednej Európe so snahou prinášat filmové diela tematizujúce spoločnú históriu nášho regiónu. Slovenská kinematografia a jej tvorcovia participovali napr. na koprodukčných filmoch ako Jánošík - pravdivá história, Bathory, Nedodržaný slub či Horiaci ker. Viaceré tieto koprodukčné projekty boli realizované aj s podporou Audiovizuálneho fondu, ktorý po svojom vzniku v roku 2009 pomohol znovunaštartovat rozvoj filmového priemyslu u nás.

Už začiatkom roku 2009 sa v slovenských médiách objavili správy o tom, že v Nitre sa bude natáčat dvojdielny film o Cyrilovi a Metodovi. Prvá časṫ mala mat duchovný charakter, druhá mala byt' dobrodružnejšia. ${ }^{8}$ Projekt producenta Ján Oparteho sa neskôr zmenil na 100-minútový hraný historický film a dostal názov Cyril a Metod alebo Anjelský obraz. Mal vzniknút podla scenára

5 Ukážka z komentára: „Boh vyslyšal jeho (Konštantínove, pozn. Š. T.) prosby a jeho rukou začal písat evanjeliá v novom jazyku."

6 Tento pátos vychádza zo schematických charakterov a replík ústredných aktérov. Konštantín sa v nich sám prezentuje ako martýr („Ja umieram pre svet a svet umiera pre mňa!"), franský biskup Viching prejavuje permanentné verbálne i neverbálne pohŕdanie nielen solúnskymi bratmi, ale aj ludom Vel'kej Moravy („Vôl nevie nič, lebo je volom. Poslúcha a slúži“).

7 Štát podporil tieto filmy sumou vo výške vyše 200 miliónov korún. Vyše sedemdesiat ostatných veritelov vložilo na ich vznik sumu takmer pol miliardy korún (Petranský 2003).

8 Podla: https://www.tkkbs.sk/view.php?cisloclanku=20090123016. 
popredného slovenského scenáristu Ondreja Šulaja, v slovensko-chorvátskej koprodukcii a v réžii českého režiséra Iva Trajkova. Tento projekt mal mat’ premiéru v júli 2013, nedošlo však k jeho realizácii.

Začiatkom roku 2013 ohlásil vznik svojho celovečerného filmu s cyrilo-metodskou tematikou aj popredný slovenský režisér Juraj Jakubisko. ${ }^{9}$ Ten sa usiloval tento projekt vytvorit v širokej koprodukcii Česka, Slovenska, Ruska, Bulharska, Nórska, Ukrajiny a Kazachstanu, a oznámil tiež, že do úlohy Svätopluka by rád obsadil britského herca Ewana McGregora. Rozpočet na tento slovanský epos bol plánovaný na 17 miliónov eur, čím mal o 4 milióny eur prekročit rozpočet jeho predchádzajúceho velkofilmu Bathory. ${ }^{10}$ Velkofilm sa však, podobne ako projekt Cyril a Metod alebo Anjelsky obraz, nedočkal realizácie, prioritne z dôvodu nedostatku financií. Hoci iniciátori oboch finančne náročných projektov sa snažili v explikácii svojich projektov poukázat’ na európsky rozmer a aktuálnost' odkazu Cyrila a Metoda, ukazuje sa, že pre producentov mimo Čiech a Slovenska nie je téma Vel'kej Moravy či Cyrila a Metoda až taká atraktívna, participáciu na takomto velkom koprodukčnom projekte vnímajú ako rizikovú pre návratnost' ich investícii. ${ }^{11}$ Začína byt' evidentné, že pri filmovom spracovaní osudov Cyrila a Metoda je efektívnejšie ponúkat ho prioritne lokálnemu publiku (predovšetkým českému a slovenskému) a namiesto vízií globálnych multiplexových vel'kofilmov je vhodnejšie formátovat' ho ako komornejší produkt určený pre verejnoprávne televízie najmä slovanských krajín. Takouto cesto sa vybrali tvorcovia televízneho seriálu Cyril a Metod - Apoštoli Slovanov, ktorý mal premiéru v českej a slovenskej verejnoprávnej televízii v júli 2013.

Vznik televízneho seriálu Cyril a Metod - Apoštoli Slovanov iniciovala česká súkromná produkčná spoločnost’ Three Brothers a na jeho vzniku participovali aj d’alší producenti z Čiech, Slovenska, Srbska a Ruska. Štvordielny televízny film podla scenára Miroslava Oščatku a v réžii Petra Nikolaeva bol prezentovaný ako ukážka v súčasnosti atraktívneho žánru dokudrámy - teda diela využívajúceho primárne formu dokumentárneho filmu, ktorého isté (dramatické) pasáže sú stvárnené formou hraného filmu s profesionálnymi hercami. ${ }^{12}$ Okrem tohto televízneho cyklu štyroch 52-minútových častí, vznikol ich zostrihom hraný celovečerný film s rovnomenným názvom. Zásadným posunom 85-minútového celovečerného filmu oproti seriálu bolo vloženie pôvodne nestranného vysvetlujúceho komentára epického príbehu osudov Cyrila a Metoda - od Cyrilovho narodenia do obdobia Metodovej smrti - do úst staršieho Cyrilovho brata. Celovečerný film sa

9 Podla: https://spis.korzar.sme.sk/c/6674027/jakubisko-si-vybral-drsny-spis-do-pripravovaneho-filmu.html. Jakubisko historický velkofilm s názvom Slovanská epopeja. Tisíc rokov samoty priblížil týmito slovami: „Môj príbeh nerozpráva iba o súbojoch kedysi mocných, dnes už zabudnutých králov, ale tiež o zrode prvej ríse, ktorá sa stala prvým krôčikom k slovanskej pospolitosti a ktorá dodnes nebola predstavená na filmovom plátne. Ved'o histórii Slovanov, žijúcich na území rozprestierajúcom sa od stredu Európy až po Ural, častokrát nevedia ani naši západní susedia $v$ EU. Je to rozprávanie o pohanstve a o zložitom zrode krestanstva u Slovanov, ale tiež o túžbe byt štastným navzdory neprajnému osudu..."

Zdroj: http://www.jakubiskofilm.com/cs/.pripravujeme/.

10 S rozpočtom 13,3 milióna eur sa Bathory zaradil medzi najnákladnejšie filmy v strednej Európe.

11 V súvislosti s predchádzajúcim historickým velkofilmom filmom Juraja Jakubiska Bathory tu navyše existuje skúsenost’ s dielom, ktoré napriek mimoriadnemu diváckemu ohlasu v Čechách a na Slovensku (kde zaujalo vyše 1300000 divákov), nezarobilo ani na svoje náklady a na medzinárodnom filmovom trhu výraznejšie nezaujalo.

12 Zaradenie tohto seriálu medzi žáner dokudrámy bolo frekventovane uvádzané v propagačných materiáloch cyklu (napríklad i na webovej stránke RTVS) hoci jeho forma má mimoriadne blízko k tradičnému hranému televíznemu seriálu. Gladiš $(2015,96)$ považuje tento seriál za subžáner tzv. umeleckej dokudrámy, v ktorej (na rozdiel od faktuálnej dokudrámy) prevažujú hrané pasáže nad dokumentárnymi. V prvej časti seriálu nazvanej Bratia zo Solúna tvoria hrané pasáže až 84, 57\% celkovej dížky filmu (ibid.). 
opiera predovšetkým o dramatické pasáže zo štvrtej časti seriálu. Dramatickejšia filmová verzia televízneho projektu však prekvapivo oslovila viac divákov v televíznom vysielaní a na DVD nosičoch ako v kinách. ${ }^{13}$

Televízny seriál (a následne aj film) priniesol po premiére rozpačité reakcie divákov i odbornej kritiky. Odbornejšie reflexie vyčítali dielu istý neobjektívny pohlad na historické súvislosti pôsobenia Cyrila a Metoda na Velkej Morave, resp. isté skreslenie historických faktov s cielom zvýraznit prínos vierozvestcov (i Vel'kej Moravy) pre súčasnú českú a moravskú kultúru a národnú identitu. Už v úvodných titulkoch českej verzie filmu je poznámka, že film bol „natočený k 1150. výročiu od príchodu Cyrila a Metoda na územie dnešnej Moravy. "V slovenskej verzii filmu je naopak v úvodných titulkoch korektná poznámka, že Velká Morava nie je totožná zo súčasnou Moravou. V seriálovej verzii projektu sa na mape, zobrazujúcej pút Cyrila a Metoda, objavuje územie označené Morava (nie Vel'ká Morava) a sídlo kniežata Rastislava Veligrad je situované na severovýchod od moravských Mikulčíc. Televízny seriál nezakrýva snahu získat’ si priazeň predovšetkým českého a moravského publika a nekriticky vyzdvihuje vztah solúnskych bratov k moravskej a českej kultúre a histórii. Tento zámer je však pre slovenského diváka tažko akceptovatelný. Zamlčiavanie vel'komoravských lokalít nachádzajúcich sa na území Slovenska a cyrilo-metodského prínosu pre slovenskú kultúru prekvapuje aj z dôvodu, že na tomto koprodukčnom seriáli participovala (hoci menšinovým podielom) aj slovenská verejnoprávna televízia. ${ }^{14}$

Predovšetkým slovenských divákov mohlo v televíznom seriáli prekvapit negatívne zobrazenie nitrianskeho kniežata Svätopluka v kontraste s jeho zidealizovaným strýkom Rastislavom. Už samotné herecké obsadenie napomáha schematickému a protikladnému zobrazeniu dvoch popredných vládcov Velkej Moravy - kým moravské knieža Rastislav je v podaní slovenského herca Milana Bahula (tradičného predstavitela kladných hrdinov) rozvážnym, dôstojným a úctu vyvolávajúcim panovníkom, jeho synovec Svätopluk v podaní Jana Jankovského pôsobí dojmom agresívneho nekultivovaného výrastka. Svätopluk je v Nikolaevovom filme stvárnený ako lokaj Východofranskej ríše, ktorý sa neštíti zajat’ svojho strýka Rastislava a vydat ho Karolmanovi. Seriál zatajuje fakt, že Rastislav sa pred týmto činom usiloval o Svätoplukove zavraždenie, kedže jeho synovec v roku 870 po franskom plienení uznal zvrchovanost' Východofranskej ríše nad územím (Nitrianskym kniežatstvom), ktoré spravoval. Televízny projekt zobrazuje aj konflikty Svätopluka s Metodom, ktorý mu vyčíta nielen jeho nemorálny životný štýl (napríklad orgie s viacerými ženami), ale aj inklináciu k východofranským duchovným - predovšetkým Vichingovi. Viching je $\mathrm{v}$ seriáli zobrazený ako intrigán bažiaci po moci a z toho dôvodu je najvýraznejším neprajníkom misie Cyrila a Metoda. Takýto negatívny obraz Vichinga je v stredoeurópskej literatúre a dráme (predovšetkým od obdobia národného obrodenia v 19. stor.) typický, v Nikolaevovom projekte je však táto postava podaná mimoriadne schematicky, ovel’a menej invenčne a plasticky, ako napríklad v Hasprovej inscenácii Solúnski bratia.

Seriál Cyril a Metod - Apoštoli Slovanov prezentuje jednoznačne negatívny pohlad na pôsobenie východofranských biskupov na území Vel'kej Moravy, obchádza podstatný fakt, že práve oni priniesli krestanstvo na územie Vel'kej Moravy. V televíznom projekte je okolie moravského Veligradu zobrazené ako málo christianizované a zaostalé. V scéne príchodu Cyrila a Metoda na Vel'kú Moravu stretávajú bratia zo Solúna skupinu pohanov s výzorom a správaním pravekých ludí. Jedna z kritík túto scénu komentuje takto: „Je udivujúce, ako mohol byt natočený tak

13 Film v roku 2013 videlo v českých kinách zanedbatelných 1666 divákov, no verejnoprávne televízie v Čechách i na Slovensku ho frekventovane zaradujú do vysielania počas sviatku sv. Cyrila a Metoda 5. júla.

14 Slovenská verejnoprávna RTVS podporila tento televízny projekt sumou 120 tisíc eur (pri celkovom rozpočte vyše 2130000 eur). 
etnograficky chabý film, $v$ ktorom je zosmiešneným, urážlivým, ba až nevierohodným spôsobom vykreslovaná naša skutočná, pôvodná duchovná kultúra" (Žiarislav 2013). V inej kritike filmu sa stretávame aj s korektnou poznámkou, že „protisvätoplukovský tón celého filmu je nenáležitý a jasne odhaluje zámer tvorcov postavit do rozporu akési proslovanské a protislovanské sily" (Čulen 2013). Favorizovanie veligradského kniežata Rastislava ako oddaného reprezentanta slovanských záujmov a najúprimnejšieho spojenca Cyrila a Metoda posilňuje mýtus o súčasnej Morave ako najkrestanskejšej a najslovanskejšej časti niekdajšej Vel'kej Moravy.

Seriál Cyril a Metod - Apoštoli Slovanov (a rovnomenný film) neskrýva dominantný zámer uctit’ si a propagovat' odkaz sv. Cyrila a Metoda. Pietny postoj k svätcom zo Solúna však akoby tvorcom zväzoval ruky postavit’ originálnejší a divácky atraktívnejší príbeh. Problematickou stránkou televízneho seriálu je nielen jeho didaktickost' a popisnost', umelecká dokudráma je plná historických nepresností či zjednodušení. Formálne spracovanie cyklického diela je konvenčné, odkazuje na tradičné televízne inscenácie, $v$ ktorých dominujú rozsiahle ateliérové scény (sídla panovníkov, interiéry kláštorov). V seriálových dialógoch dominuje literárny jazyk a v jednotlivých replikách sa nachádza aj neúmerné množstvo pátosu, takže aj skúsení herci obsadení v projekte často zlyhávajú v snahe dat postavám ludský rozmer. Koprodukčný projekt síce napíňa zámer vzdelávacieho a pietneho diela, rezignuje však na ambície ponúknut divácky atraktívny a uveritelný obraz významného mílnika našich dejín.

\section{Dokumentárna reflexia prínosu solúnskych bratov}

V roku 2014 bol na Slovensku realizovaný ambiciózny televízny projekt tematizujúci príchod Cyrila a Metoda na územie Velkej Moravy. Išlo o trojdielny dokumentárny film Misia bratov Konštantína a Metoda, ktorý podla scenára Bernadety Tokárovej zrežíroval Kristián Bezák. Scenáristka Bernadeta Tokárová sa v Redakcii duchovného života Slovenskej televízie podielala na vzniku niekol'kých dokumentov, ktoré sa venovali tejto problematike, ešte pred rokom 2000, no podla jej slov neboli také analytické (Eliášová 2014). Ambíciou tvorcov bolo vytvorit’ komplexnejší pohlad na problematiku a obohatit televízne svedectvo o niektoré nové poznatky, ktoré sa objavili v poslednom desatročí.

Dokumentárny seriál Misia bratov Konštantína a Metoda nakrúcal štáb RTVS v deviatich krajinách Európy, navštívil pritom 23 rôznych bazilík a kostolov, niekolko múzeí, ba i vatikánske tajné archívy. Finálny materiál je rozdelený do troch približne 52-minútových častí, ktoré chronologicky popisujú osudy Konštantína a Metoda od ich príchodu na Vel'kú Moravu. Seriál je zložený z výpovedí popredných historikov, archeológov, jazykovedcov či teológov nielen zo Slovenska, ale aj z Grécka, Srbska, Madarska či Nemecka. Tie sú spojené komentárom so zábermi historických prevažne sakrálnych - stavieb, mapami historických území a detailmi obrazov a fresiek s cyrilo-metodskými a vel'komoravskými motívmi.

Prvá časṫ trojdielneho cyklu je venovaná príchodu Konštantína a Metoda na Vel'kú Moravu. Dokument posudzuje ich misiu nielen z cirkevného pohladu, ale velmi podrobne analyzuje aj ich kultúrny prínos. Písmo, ktoré Konštantín vytvoril - hlaholika - je v dokumente priblížené aj z jazykovedného hladiska, objasňuje sa tu aj charakter Konštantínovej oslavnej piesne Proglas. Divák sa tu zoznamuje aj s novými archeologickými nálezmi z 9. storočia na Devíne, ktoré môžu byt základmi sakrálnej vel'komoravskej stavby. Devín je tu spomínaný ako Rastislavove sídlo, ktoré Fuldské anály označujú ako Dowina. Druhá čast' dokumentu približuje pút Konštantína a Metoda a ich učeníkov do Benátok v roku 867, kde Konštantín obhájil spor o používanie slovanského jazyka v liturgii s trojjazyčníkmi. Historici potom opisujú aj návštevu gréckych bratov u pápeža Hadriána II. v Ríme, ktorý v rovnakom roku schválil slovanské bohoslužobné knihy a povolil 
slovanskú liturgiu. Pri návrate Metoda na Velkú Moravu v roku 870 ho na pokyn franských biskupov internovali v kláštore v Elwangene. Dokument divákov privádza aj do tohto mesta, kde nájdeme reliéf znázorňujúci ponižovanie Metoda franskými biskupmi. V úvode tretej časti dokumentu je priblížený prínos Konštantína a Metoda pre cirkevné dejiny a rozoberá aj vzájomný vztah Svätopluka a Metoda. Dokument rozbíja stereotypný názor, že Svätopluk vyhnal Metodových žiakov z územia Velkej Moravy. V životopise, ktorý napísal svätý Kliment, sa uvádza, že boli vyhnaní za neprítomnosti Svätopluka vo svojom sídle.

Seriál Misia bratov Konštantína a Metoda je ukážkou formálne konvenčného, ale zároveň remeselne kvalitne natočeného televízneho cyklického dokumentu. Zaujme kvalitným výberom účinkujúcich odborníkov na danú problematiku a aj zábermi na mnohé verejne doposial nepublikované dokumenty. Divákom prvýkrát sprostredkúva originál Buly Jána VIII. Industriae tuae z roku 880. Približuje aj jednu z najvzácnejších cyrilo-metodských pamiatok napísanú hlaholikou - Assemanov kódex, ktorý je uložený vo Vatikánskej knižnici. Prístup do tejto knižnice bol filmárom umožnený aj vdaka záštite významných slovenských cirkevných predstavitelov a zároveň odborníkov na cirkevnú históriu - profesorky Emíle Hrabovec, profesora Viliama Judáka a profesora Cyrila Vasila, ktorí sa v dokumentárnom seriáli frekventovane objavujú. Napriek relatívne reprezentatívnej vzorke účinkujúcich odborníkov z mnohých európskych krajín, prekvapí absencia českých (či skôr moravských) vedcov. Za jediné velkomoravské mestá sú podla prvej časti dokumentu považované Devín, Bratislava a Nitra. Je tažko pochopitel’né, prečo sa v dokumente neobjavuje slovom či obrazom žiadna moravská lokalita ${ }^{15}$, nie je v ňom tiež zmienka o najfrekventovanejšie prezentovanom Rastislavovom sídle Veligrad, ktoré sa zvykne lokalizovat na územie dnešnej juhovýchodnej Moravy. Snaha dokumentu priblížit (a zvýraznit') prínos Cyrila a Metoda pre slovenskú kultúru je korektná, no snaha lokalizovat’ cyrilo-metodskú misiu (rovnako ako napríklad pôsobenie kniežata Rastislava) výlučne pre súčasné územie Slovenska je problematická. Takýto postoj sa dá čítat aj ako lojalita autorov dokumentu k aktuálne vládnucej politickej reprezentácii, ktorá sa snaží oživit’ svätoplukovský mýtus a vo Vel'kej Morave či v Svätoplukovom nitrianskom kniežatstve nachádza korene slovenskej štátnosti. ${ }^{16}$

Ďalší podnetný a mnohovrstevný dokument o živote solúnskych bratov a ich misii na Velkej Morave vznikol v Českej televízii v roku 2013 pod názvom Cyril a Metoděj: Dédictví otců a matek zachovej nám, Pane! Tento 52-minútový film podla scenára Otakára Mariu Schmidta režijne spracovali Otakáro Maria Schmidt, a Jana Kristina Studničková. Dokumentárny film s prvkami filmovej eseje využíva sprievodný komentár Martina Dejdara a autora filmu Otakára Mariu Schmidta, ktorí približujú životnú pút, ale i osobnostné rysy Konštantína a Metoda. Osvetlujú ich úradnícke i misijné pôsobenie v Byzantskej ríši, vyzdvihujú Konštantínov talent a vzdelanost', predovšetkým v oblasti jazykov. Ďalšími sprievodcami dokumentu je dvojica súčasných českých kňazov Miroslav Herold a Marek Orko Vácha, ktorí v inscenovaných pasážach stvárňujú solúnskych bratov a rekonštruujú ich cestu z Byzantskej ríše na Velkú Moravu a neskôr i do Talianska. Štáb dokumentaristov s kamerou navštevujú nielen tradičné miesta spojené s pobytom Cyrila a Metoda ako Solún, Istanbul, Benátky a Rím, ale aj miesta spojené s cyrilo-metodským odkazom ako Ochrid v Macedónsku, miesta v Bielorusku, na Kryme, českú Starú Boleslav, moravské Stř́lky či Velehrad.

V porovnaní so slovenským dokumentom Misia bratov Konštantína a Metoda, má český film Cyril a Metoděj: Dědictví otců a matek zachovej nám, Pane! originálnejšiu vizuálnejšiu stránku

15 Až v tretej časti seriálu sa na mape Velkej Moravy objaví aj moravské mesto Mikulčice.

16 V dokumente sa objavujú zábery sochy Svätopluka na Bratislavskom hrade, ktorú v roku 2012 odhalil predseda vlády SR Robert Fico. 
i štruktúru ${ }^{17}$, no rovnako sprostredkúva pohlad na cyrilo-metodskú tému predovšetkým prostredníctvom interpretácie súčasných predstavitelov cirkvi. Film Otakára Mariu Schmidta dáva výrazný priestor výpovediam popredných českých i slovenských cirkevných hodnostárov: napr. pražskému arcibiskupovi Dominikovi Dukovi, arcibiskupovi olomouckému Janovi Graubnerovi, či jezuitovi Cyrilovi Vasilovi - sekretárovi pre východné cirkvi. Prínosnou pasážou dokumentu je sumarizovanie prínosu pre českú a moravskú kultúru - venuje sa napríklad aj úlohe krála Karola IV pri šírení cyrilo-metodského odkazu. Za miesto posledného Metodovho odpočinku sa podla televízneho filmu považuje súčasná Morava - či už Velehrad, Hora sv. Klimenta v Chřibech, pri Uherskom Hradišti či pri Mikulčiciach. Dokumentárny film priznáva, že hoci hmatatelné pamiatky na solúnskych bratov na Morave neexistujú, no ich duchovný odkaz je stále prítomný a intenzívny.

\section{Postmoderný a ironizujúci pohl'ad na cyrilo-metodskú tradíciu}

V aktuálnom tisícročí sa čoraz frekventovanejšie objavuje aj menej pietny pohlad na cyrilo-metodskú tradíciu. Diela, zvyčajne šírené na internetovej platforme, komunikujúce s prevažne s mladou generáciou, využívajú aj ironický či priamo parodický prístup k tejto tematike.

Už v roku 2008 v rámci českého animovaného televízneho seriálu podla úspešnej knihy Lucie Seifertovej Dějiny udatného českého národa, v ktorom sa autori hravou a humornou formou snažili približit klúčové momenty českých dejín, sa diváci mohli stretnút aj s epizódou približujúcou príchod Cyrila a Metoda na Vel'kú Moravu. Kreslený trojminútový film v réžii Pavla Koutského a s komentárom Jiř́ho Lábusa, ponúka zjednodušený a humorný pohlad na postavy solúnskych bratov. V krátkom filme sú komicky štylizované postavy Cyrila Metoda zobrazené so svätožiarami, ktoré si navzájom zamieňajú. Hlaholiku prinášajú miestnemu obyvatel'stvu doslovne sypú obrovské písmená kniežatu Rastislavovi do náručia, následne sa obyvatelia Velkej Moravy (v seriáli Moravy) s písmenami začínajú zvedavo hrat. Irónia je prítomná aj v scéne zobrazenia sviatosti krstu. Komentár o tom, že obyvatelia krst prijímali s radostou kontrastuje s kreslenou scénkou, v ktorej Cyril a Metod naháňajú, chytajú a hádžu vydesených ludí do vel'kej kade, kde im následne požehnávajú. Záverečný obraz Božieho oka nad Velkou Moravou s komentárom, že v Čechách krestanstvo zapustilo svoje pevné korene, sa tiež dá čítat viacznačne. Humor seriálu i konkrétnej epizódy je však evidentne láskavý, slúži do istej miery didaktickej funkcii a neskĺzava do ostrej satiry. Tú môžeme nájsț v epizóde Cyril a Metod (2014) z cyklu Kapurková, ktorá sa nachádza na webstránke lokaltv.sk. ${ }^{18}$ Internetová epizóda z dielne režiséra Jakuba Kronera nám ponúka krátku mystifikáciu o živote Cyrila a Metoda plnú absurdných situácií, ktorú divákom prednáša podnapitý kňaz. Terčom posmechu epizódy, a vlastne celého cyklu Kapurková, evidentne nie sú solúnski bratia, ale podgurážený kňaz. Cez túto zmätenú postavičku sa tvorcovia Kapurkovej pokúšajú o konvenčnú proticirkevnú satiru.

Cyril a Metod sú v súčasnosti využívaní nielen v ironických a satirických programoch, ale aj $\mathrm{v}$ internetových kampaniach na podporu krestanských aktivít. V roku 2013 ich kreslené postavičky pozývali v klipe, ktorý na portáli youtube.com zdielal Katechetický úrad spišskej diecézy, na Národný pochod za život v Košiciach. ${ }^{19}$ Dialóg dvojice svätcov je konvenčný, varuje pred hroz-

\footnotetext{
17 Netradičným prístupom v tomto dokumentárnom filme s prvkami faktuálnej dokudrámy je využitie rovnakých aktérov (Miroslav Herold, Marek Orko Vácha) v dokumentárnych a zároveň v inscenovaných pasážach. Dokument zaujme aj množstvom štylizovaných, symbolických, poetických i hravých obrazov a vynaliezavou subjektívnou a dynamickou kamerou Jiř́ího Strnada.

18 Video dostupné na: http://www.lokaltv.sk/kapurkova-cyril-a-metod/623/46.

19 Video dostupné na: https://www.youtube.com/watch?v=ND-31nGk400.
} 
bou potratov na Slovensku. Vizuál postavičiek solúnskych bratov však evidentne odkazuje na hrdinov amerického seriálu South Park, ktorý je typický svojím provokatívnym hrubozrným humorom a ostro-satirickým spoločenským postojom. Nekonvenčný vizuál svätcov sa snaží oslovit predovšetkým mladú generáciu veriacich, no i mládež s vlažnejším postojom k cirkvi.

V roku 2017 sa na lifestylovej slovenskej internetovej stránke vju.sk objavil webseriál Soloon Brothers. Jedenást’ webizód režiséra Gejzu Dezorza a scenáristov Juraja Malíčka a Pavla Hubináka využíva v hlavných úlohách postavy vierozvestcov zo Solúna, hrané dielo je však výrazne odlišné od tradičných historických životopisných diel. Webseriál sa dominantne opiera o žánre sci-fi a situačnej komédie. Vierozvestci Konštantín Cyril a Metod v ňom cestujú na Vel'kú Moravu, no kedže nestihli prvý termín príchodu, skúšajú sa tam dopravit nielen cestovaním v priestore, ale aj v čase. Takúto pút im umožní a sprevádza ich ňou učenec, lekár a alchymista Nostradamus. Netradičnej trojici cestovatelov v čase sa nedarí nájst presné miesto a čas ich cesty, preto sa objavujú v rôznych historických obdobiach a stretávajú rôzne významné postavy, ktoré sú spojené so slovenskou históriou, vedou či kultúrou. Medzi epizódne postavy tak patria napríklad Ján Hollý, Ján Jesenius, Ludovít Štúr, Juraj Jánošík, Jozef Murgaš či Kupec Samo.

Vo webseriáli s originálnym námetom sa predstavila trojica popredných komediálnych hercov Lukáš Latinák, Juraj Kemka a Miroslav Noga. Režisér zvolil pri jeho inscenovaní minimalistický prístup - mizancény vytvára okrem hercov a rekvizít zvyčajne len fotografiou/videosekvenciou na pozadí. Podla tvorcov vo webseriáli sa „pracuje s iróniou, sarkazmom, sebairóniou, absurditou a dada, čo sú komediálne prvky, s ktorými sa síce v domácom prostredí nedá velmi pracovat $v$ hlavnom prúde... ${ }^{\text {20 }}$ Predovšetkým prvé epizódy priniesli rozpačitý humor, neujasnenú štruktúru i minutáž v rozpätí od 5 do 11 minút. Postava zo slovenskej histórie (stvárnená vždy M. Nogom), ktorú solúnski bratia stretávajú, je zobrazená s komickou štylizáciou, a kým v niektorých epizódach je terčom rád Cyrila a Metoda, ako by sa mal zapísat do histórie, v dalších zas on udivuje svätcov svojimi schopnostami.

Napriek relatívne dobrej propagácii na internetovej platforme si seriál Saloon Brothers nenašiel vela priaznivcov ${ }^{21}$. Dôvodom nie je len istá dramaturgická nedotiahnutost', ale aj fakt, že tento seriál si vyžaduje diváka značne poučeného o živote (i tvorbe) jeho hrdinov. Dá sa predpokladat', že takýchto nadpriemerných znalcov slovenskej histórie a jej dejatelov medzi cielovou skupinou lifestylovej webstránky vju.sk - mladých ludí do tridsat rokov - nie je vela. Na druhej strane je evidentným prínosom Soloon Brothers jeho snaha približovat velikánov našej kultúry bez tradičného pátosu, hoci jeho hrdinovia, vrátane Konštantína Cyrila a Metoda, sú skôr zdrojom a terčom láskavého humoru než ostrého sarkazmu a satiry. Seriál Juraja Malička a Pavla Hubináka je postmoderným dielom, ktoré síce pracuje s tradičnými mýtmi, ale snaží sa ich narúšat. Vytvára priestor pre diskusiu o význame našich historických osobností a môže prispiet’ i k prehodnocovaniu spoločenského postoja k významným mílnikom našej histórie.

\section{Záver}

Cielom tejto prehladovej štúdie bolo priblížit a analyzovat relevantné české a slovenské audiovizuálne diela venované životu a tvorbe svätých Cyrila a Metoda od konca 80. rokov minulého storočia po súčasnost'. Práca odhalila posuny v pohlade na túto problematiku pod vplyvom zmien spoločenskej a politickej situácie v posledných troch dekádach. Počas komunistickej vlády v Československu boli sv. Cyril a Metod na okraji mediálneho záujmu a boli vnímaní len ako

20 Zdroj: https://www.facebook.com/SoloonBrothers/.

21 Fanúšikovská stránka tohto seriálu mala na sklonku januára 2019245 priaznivcov. 
tvorcovia prvého slovanského literárneho jazyka a abecedy, prípadne aj ako údajní bojovníci proti násilnej germanizácii. Problematické bolo ich poslanie ako šíritelov krestanstva a významných predstavitelov cirkvi. Aj v televíznej inscenácii Solúnski bratia z roku 1988 sú Cyril a Metod vyzdvihovaní predovšetkým ako významní obhajcovia Slovanov a morálne autority, ich rozmer náboženských predstavitelov je v úzadí. Až po roku 1989 začínajú byt' tieto historické postavy výraznejšie prezentované ako predstavitelia cirkvi a zásadní šíritelia krestanstva na našom území. Po vzniku Slovenskej republiky v roku 1993 sú solúnski bratia ešte intenzívnejšie spájaní s koreňmi našej štátnosti. V slovenských dokumentárnych i hraných televíznych projektoch sa pozornost̉ zameriava na ich pôsobenie na súčasnom slovenskom území a vyzdvihuje sa ich prínos predovšetkým pre slovenskú kultúru a cirkev. Privlastňovanie si odkazu Cyrila a Metoda nie je typické iba pre slovenské televízne projekty. V jedinom zrealizovanom celovečernom filme o ich živote a tvorbe s názvom Cyril a Metod - Apoštoli Slovanov, ktorí iniciovali českí producenti (hoci aj s účastou zahraničných koprodukčných partnerov), je nekriticky vyzdvihovaný vztah Cyrila a Metoda k súčasnému územiu Moravy i k panovníkom, ktorí na ňom (údajne) pôsobili. Po roku 1993 začína vznikat’ výrazná priepast’ v interpretácii cyrilo-metodskej tradície medzi českými a slovenskými audiovizuálnymi tvorcami. Títo sa často orientujú na posilňovanie národných mýtov, no týmto zároveň rezignujú na hladanie objektívnej historickej pravdy. Ďalším negatívnym dôsledkom takéhoto tvorivého prístupu je často aj strata komunikatívnosti a atraktívnosti diel s cyrilo-metodskou tematikou mimo krajiny ich pôvodu.

V období rokov 2013 až 2014 vnikli dva pozoruhodné dokumentárne filmy o živote a tvorbe solúnskych bratov - český Cyril a Metoděj: Dědictví otců a matek zachovej nám, Pane! a slovenský Misia bratov Konštantína a Metoda. Obe snímky sú charakteristické snahou o komplexnejší a objektívnejší pohlad na spomínaných svätcov, no v oboch je prítomná národná perspektíva i výrazný náboženský pohlad.

V súčasnosti vznikajú aj diela s menej pietnym pohladom na cyrilo-metodskú tradíciu. Sú šírené často aj na internetovej platforme, oslovujú prioritne mladú generáciu a využívajú aj ironický či parodický prístup k tejto tematike. Epizóda z českého animovaného cyklu Dějiny udatného českého národa, epizóda zo slovenského animovaného internetového cyklu Kapurková či slovenský postmoderný webseriál Soloon Brothers popularizujú túto tému aj v rámci publika, pre ktoré je tradičný pohlad na solúnskych bratov neatraktívny. Uchovávajú tým cyrilo-metodský diskurz v povedomí širšieho obyvatel'stva a majú tiež potenciál ovplyvňovať aktuálny spoločenský postoj k Cyrilovi a Metodovi a ich odkazu.

\section{REFERENCES}

Čulen, Anton. 2015. Protislovenská interpretácia CM misie: Cyril a Metod - Apoštoli Slovanov. Film, ktorý nesplnil očakávania. http://alianciazanedelu.sk/?p=6118.

Eliášová, Andrea. 2014. Slovenský dokument Misia bratov Konštantína a Metoda žne ohlasy a prináša aj niektoré prekvapenia. https://www.rozhlas.cz/nabozenstvi/zpravy/_zprava/slovensky-dokument-misia-bratov-konstantina-a-metoda-zne-ohlasy-a-prinasa-aj-niektore-prekvapenia--1375562.

Gladiš, Marián. 2015. Dokudráma a jej podoby v súčasnom slovenskom mediálnom prostredí. In Bočák, Michal - Regrutová, Lenka - Rusnák, Juraj (eds.). Médiá a text 5. Prešov, 81-101.

Kopal, Petr. 2014. Velká Morava - pokus o slovenský národní velkofilm. In Kopal, Petr (ed.). Film a dějiny 4. Normalizace. Praha, 202-219.

Lauková, Silvia (ed.). 2013. Medzi trvaním a dejinami. Cyril a Metod v slovenskej literatúre. Výberová antológia. Nitra. 
Petranský, Ludo. 2003. Slovenský film - zabudni na Kolibu? https://www.sme.sk/c/833986/ slovensky-film-zabudni-na-kolibu.html.

Turčan, Vladimír. 2013. Cyril a Metod - trvalé dedičstvo. In Krekovič, Eduard - Mannová, Eva Krekovičová, Eva (eds.). Mýty naše slovenské. Bratislava, 36-41.

Žiarislav. 2013. Cyril a Metod - utajený zákonník - 4-dielna filmová rozprávka sa naštastie skončila. http://www.2012rok.sk/wp/ako-dalej/17590-cyril-metod-utajeny-zakonnik-4-dielnafilmova-rozpravka-sa-nastastie-skoncila.

\section{SUMMARY: REFLECTION OF THE LIFE AND WORK OF CYRIL AND METHODIUS} IN TELEVISION, FILM AND INTERNET PRODUCTION FROM THE 1980S TO THE PRESENT. The aim of the study was to analyze relevant Czech and Slovak audiovisual works devoted to the life and work of Saints Cyril and Methodius since the end of the 1980s to the present. The work revealed shifts in this subject under the influence of changes in the social and political situation in the last three decades. During the Communist regime in Czechoslovakia, Cyril and Methodius were on the margin of media interest and were perceived only as creators of the first Slavic literary language and alphabet, or as fighters against violent Germanization. Their missions as Christians and important church officials were perceived as problematic. In the television production called Solunski bratia (Brothers from Thessaloniki) made in 1988, Cyril and Methodius are particularly highlighted as important advocates of the Slavs and moral authorities, their role as religious leaders was diminished. After 1989, these historical figures began to be presented as Church representatives and fundamental promoters of Christianity in our territory. After the foundation of the Slovak Republic in 1993, the brothers from Thessaloniki became connected to the roots of Slovak statehood. In Slovak documentary and featured television projects, they were mainly associated with the work within the present Slovak territory and their contribution to Slovak culture and the Church was particularly highlighted. Cyril and Methodius were not exclusively used just in Slovak TV projects. In Cyril a Metod Apoštolové Slovanů (Cyril and Methodius - Apostles of the Slavs), the only film specifically devoted to their life and work initiated by Czech producers (with the participation of foreign co-productive partners), the relationship of Cyril and Methodius and their work on the present territory of Moravia is uncritically highlighted.

Two remarkable television documentary films on the life of the brothers from Thessaloniki were created in 2013 and 2014. The Czech documentary Cyril a Metoděj: Dédictví otců a matek zachovej nám, Pane! (Cyril and Methodius: Lord, preserve the legacy of our fathers and mothers for us!) and the Slovak film Misia bratov Konštantína a Metoda (Mission of the Brothers Constantine and Methodius). Both documentary productions are characterized by the desire for a more complex and more objective view of the saints, but both national perspectives and a distinct religious view are present.

In the current millennium, works are also being created with less respectful views of the Cyrillo-Methodic tradition. They are commonly distributed on the Internet platform, they typically use irony and parody and they address primarily the young generation. The postmodern web series such as Soloon Brothers can help us to rethink the social attitude towards Cyril and Methodius and their heritage. 
Mgr. art. Štefan Timko, PhD.

Constantine the Philosopher University in Nitra

Faculty of Central European Studies

Institute of Languages and Cultures of Central Europe

Dražovská 4

94974 Nitra

Slovakia

stimko@ukf.sk 